\title{
METHODOLOGICAL IMPLICATIONS OF NEW RADIOCARBON DATES FROM THE EARLY HOLOCENE SITE OF KÖRTIK TEPE, SOUTHEAST ANATOLIA
}

\author{
Marion Benz ${ }^{1}$ • Aytaç Coşkun ${ }^{2}$ Irka Hajdas ${ }^{3}$ - Katleen Deckers ${ }^{4}$ - Simone Riehl ${ }^{4,5} \bullet$ \\ Kurt W Alt ${ }^{6} \cdot$ Bernhard Weninger $^{7} \cdot$ Vecihi Özkaya ${ }^{2}$
}

\begin{abstract}
One of the greatest challenges of contemporary archaeology is to synthesize the large amount of radiocarbon and archaeological data into a useful dialogue. For the late Epipaleolithic and the Early Neolithic of the Near East, many ${ }^{14} \mathrm{C}$ ages have been published without precise stratigraphic documentation. Consequently, for archaeological age models we often must use some more elementary approaches, such as probabilistic summation of calibrated ages. The stratigraphy of Körtik Tepe allows us for the first time to study an extended series of ${ }^{14} \mathrm{C}$ ages of the earliest Holocene. In particular, we are able to analyze the data according to stratigraphic position within a well-documented profile. However, because of a plateau in the ${ }^{14} \mathrm{C}$ age calibration curve at the transition from the Younger Dryas to the Early Holocene, dates of this period can be interpreted only if an extended sequence of dates is available. Due to problems remaining in the calibration procedure, the best way to achieve an interpretation is to compare the results of different ${ }^{14} \mathrm{C}$ calibration software. In the present paper, we use the results of the calibration programs $\mathrm{OxCal}$ and $\mathrm{CalPal}$. This approach has important implications for future age modeling, in particular for the question of how to date the transition from the Epipaleolithic to the PPNA precisely and accurately.
\end{abstract}

\section{INTRODUCTION}

In the early days of radiocarbon dating, even single ${ }^{14} \mathrm{C}$ ages provided invaluable information for the absolute chronology of archaeological sites. It has become a challenge to interpret correctly the increasingly large archaeological ${ }^{14} \mathrm{C}$ database in order to reconstruct processes in human prehistory. Some significant archaeological and statistical filtering is necessary (e.g. Bayliss 2009). Whereas the technology of ${ }^{14} \mathrm{C}$ dating has itself made enormous progress (Hajdas 2009), many of the earlier measured ${ }^{14} \mathrm{C}$ dates for the Epipaleolithic-Neolithic transition in the Near East were published without much stratigraphic detail. Consequently, even large-scale data compilations (e.g. http:// www.exoriente.org/associated_projects/ppnd.php) can provide only a broad impression as to the chronological relationships between the different archaeological sites (Benz 2000; Aurenche et al. 2001; Weninger et al. 2009). During the studied period, even the relative time sequence of sites, processes, and events is in many cases difficult to evaluate. Judgments about the reliability of ${ }^{14} \mathrm{C}$ data are therefore often based on the plausibility (or implausibility) of the observed ${ }^{14} \mathrm{C}$ age of different dated materials. In some cases, old wood samples (e.g. Finlayson and Mithen 2007:460-9) or some (possibly contaminated) bones could be identified (Otte et al. 1998:538; Denaire 2009). In other cases, problems related to sample reworking or measurement have been detected (e.g. Évin and Stordeur 2008). There are even circumstances in which ${ }^{14} \mathrm{C}$ ages on samples from contexts that were previously considered reliable may prove to be problematic, as for many of the ${ }^{14} \mathrm{C}$-dated seeds from Abu Hureyra, which were apparently from relocated deposits (http://www.exoriente.org/ associated_projects/ppnd_site.php? $\mathrm{s}=2$ ). Thus, a cautious and critical analysis of the sample provenience in each individual case is a paramount condition for chronological discussions (Perrot 2000: 11; Bayliss 2009:126). In particular, the important transition from Epipaleolithic to early Neolithic

\footnotetext{
${ }^{1}$ Department of Near Eastern Archaeology, Albert-Ludwigs-University, 79085 Freiburg, Germany. Corresponding author. Email: marion.benz@orient.uni-freiburg.de.

${ }^{2}$ Dicle Üniversitesi, Edebiyat Fakültesi, Arkeoloji Bölümü, 21280 Diyarbakır, Turkey.

${ }^{3}$ Ion Beam Physics, ETH Zürich, 8093 Zürich, Switzerland.

${ }^{4}$ Institute for Archaeological Science, Eberhard-Karls-University, 72070 Tübingen, Germany.

${ }^{5}$ Senckenberg Center for Human Evolution and Palaeoecology, Tübingen, Germany

${ }^{6}$ Institute of Anthropology, Johannes-Gutenberg-University, 55099 Mainz, Germany.

${ }^{7}$ Institute of Prehistoric Archaeology, Radiocarbon Laboratory, University of Cologne, 50923 Cologne, Germany.
}

C) 2012 by the Arizona Board of Regents on behalf of the University of Arizona Proceedings of the 6th International Radiocarbon and Archaeology Symposium, edited by E Boaretto and N R Rebollo Franco RADIOCARBON, Vol 54, Nr 3-4, 2012, p 291-304 
societies in the Near East remains to be well dated. Thus far, sophisticated models for dating samples from these periods have been used only rarely (Edwards et al. 2004).

With its stratigraphic depth of $>4 \mathrm{~m}$, the site of Körtik Tepe in southeast Anatolia offers an invaluable opportunity for dating the transitional period from the Epipaleolithic to the Pre-Pottery Neolithic A (PPNA) occupation on the boundary between the Younger Dryas (YD) and the Early Holocene. In a previous study (Benz et al. 2011), we suggested that the oldest phases (Phase VII downwards) at Körtik Tepe were occupied during the YD. In this paper, following a discussion of the stratigraphic information and using the results of different calibration programs (OxCal and $\mathrm{CalPal}$ ), we will show that it is possible to distinguish at least 6 subphases for the occupation of the site, all of which date to the earliest Holocene. The stratigraphic dating method we have applied at this site will have important methodological implications for future projects aimed at dating the beginning of the early Neolithic in the Near East.

\section{KÖRTIK TEPE: THE SITE AND ITS SETTING}

Körtik Tepe $\left(37^{\circ} 48^{\prime} 51.90^{\prime \prime} \mathrm{N}, 40^{\circ} 59^{\prime} 02.02^{\prime \prime} \mathrm{E}\right)$ is a small mound of only $5 \mathrm{~m}$ elevation. Its location near the point where the Batman Creek enters the Tigris River provided a favorable and diversified ecology for prehistoric occupation (Riehl et al. 2012). Up to 2011, 722 single and some double burials and 112 round planned structures had been excavated. The multiple renewal of house floors, the persistence in the use of space, the large number of intrasite burials, and the diversified animal spectrum (Arbuckle and Özkaya 2006; Özkaya et al. 2011) all suggest that Körtik Tepe was probably a permanent settlement, although some of the inhabitants may have left the site for seasonal activities. The Epipaleolithic/Early Neolithic strata are beneath only Medieval remains (Figure 1).

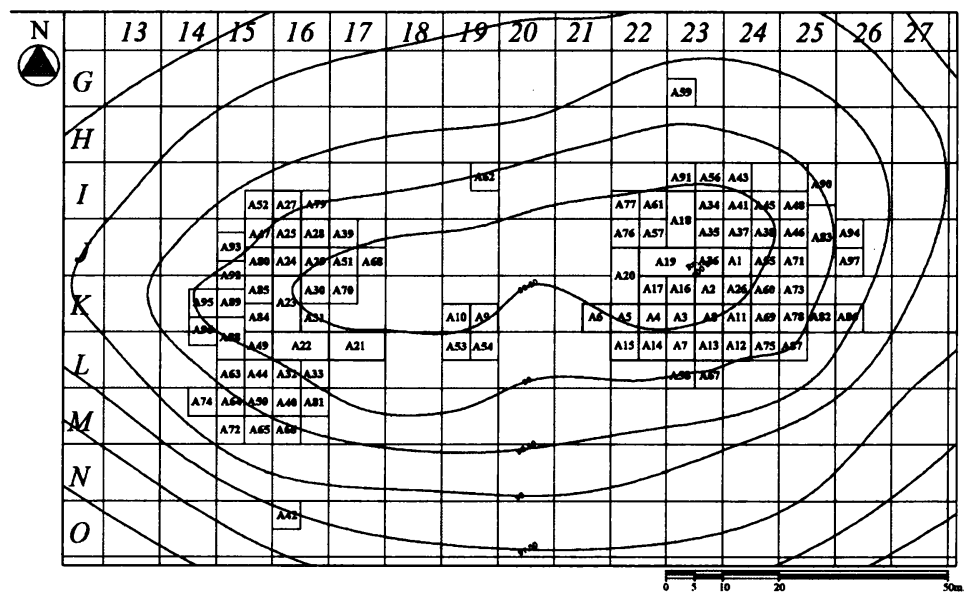

Figure 1 Excavated trenches of Körtik Tepe up to 2010. The profiles of A84 and A80 have been ${ }^{14} \mathrm{C}$ dated (plan by A Coşkun).

\section{${ }^{14} \mathrm{C}$ DATA AND STRATIGRAPHY}

${ }^{14} \mathrm{C}$ data from Körtik Tepe are listed in Table 1 . Altogether, 12 samples were processed by ${ }^{14} \mathrm{C}$ accelerator mass spectrometry (AMS) at the Laboratory of Ion Beam Physics of ETH Zurich (lab code ETH; Coşkun et al. 2010). Two additional AMS ${ }^{14} \mathrm{C}$ ages were measured at the ${ }^{14} \mathrm{C}$ AMS Leibnitz Laboratory Kiel (lab code KIA). Except for sample BP 191-2 (KIA-44864 and -44863), all samples are from the profiles of trenches A80 and A84. 


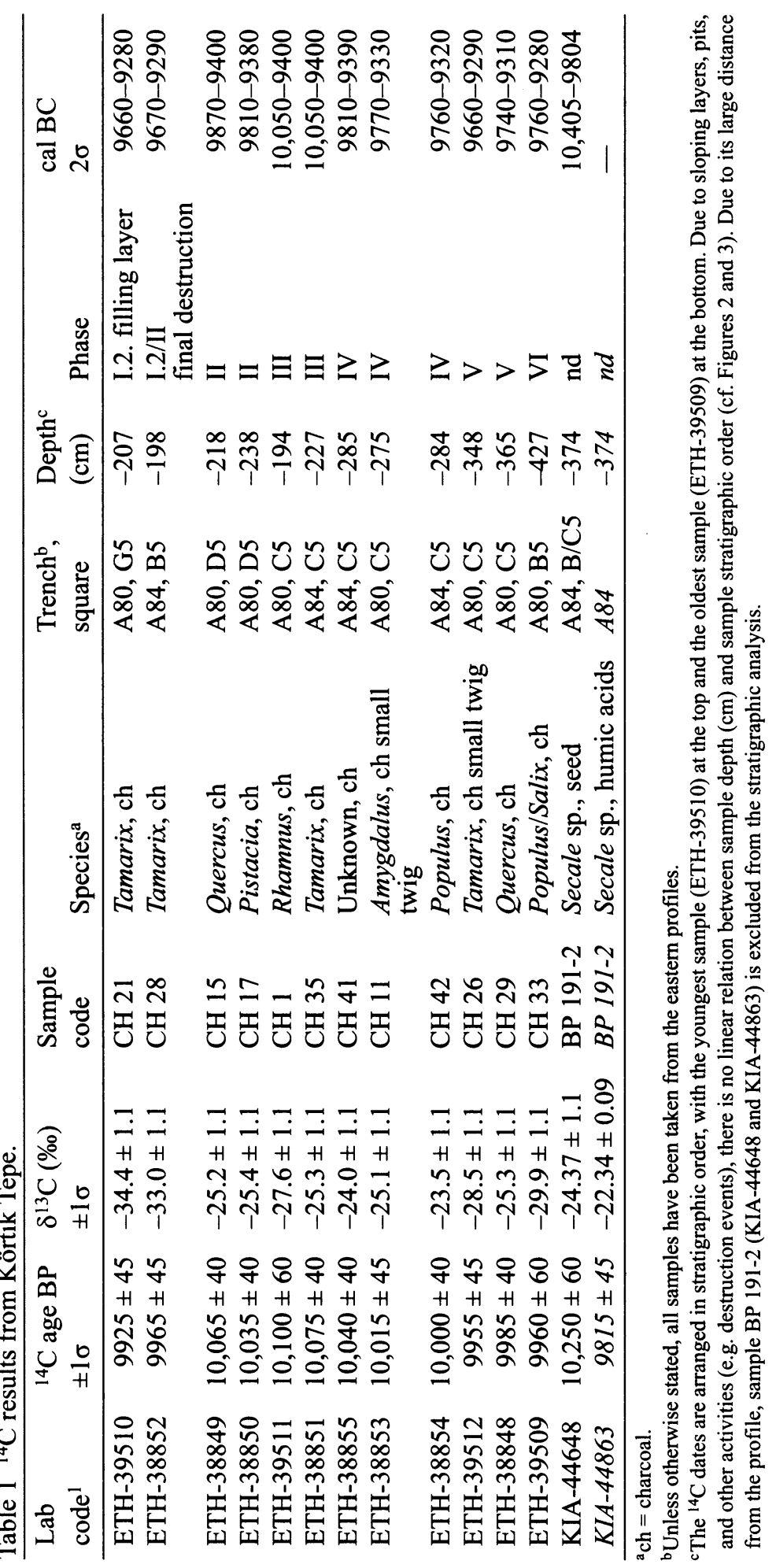


The 2 AMS measurements by the Kiel Laboratory were performed on rye seeds of the same botanical sample (BP 191-2). Sample BP 191-2 comes from a depth of -3.74 $\mathrm{m}$ in front of the eastern profile A84. The chemically purified carbon from the charred seed gave an age of 10,250 $\pm 60 \mathrm{BP}$ (KIA-44864). Since the exact stratigraphic position of this sample, in relation to the profile, has yet to be verified, this date was not included in the present statistical analysis. It is nevertheless an important ${ }^{14} \mathrm{C}$ age, since it can be roughly correlated with the older layers in the deep sounding of Trench A80 and it supports our former suggestion that the occupation of the site had already begun during the YD. Because it had too little carbon, only the humic acid of the second sample (KIA44863) could be dated. The laboratory considers the derived date of this sample too young (A Dreves, personal communication).

With the aim of constructing a stratigraphic sample sequence for Bayesian wiggle-matching, we will first discuss the stratigraphic and archaeological properties of the profiles under study and then compare the different statistical models. The documentation of Trench A80 began in 2009 (Benz et al. 2011). By the next campaign (2010), drying of the sediments made it possible to distinguish layers down to $-5.60 \mathrm{~m}$ and the natural soil (Figure 2), into which the first/oldest construction had been dug to about $50 \mathrm{~cm}$. Postholes indicate the use of wooden posts for a roof or shelter. Up to $-3.00 \mathrm{~m}$, the constructions were mostly of organic material: because of the limited area excavated, precise layouts of these buildings cannot be given. At $-3.20 \mathrm{~m}$, a pit dug down to $-4.25 \mathrm{~m}$ could be discerned: its filling consisted of several thin deposits of ash and charcoal. Above $-3 \mathrm{~m}$, the documented floors become more massive and were of pure clay. Thin layers of ash and charcoal between these clay floors indicate that they had been repeatedly renovated. A stone wall belonging to a house could be documented in the profile at $-2.50 \mathrm{~m} /-2.10 \mathrm{~m}$.

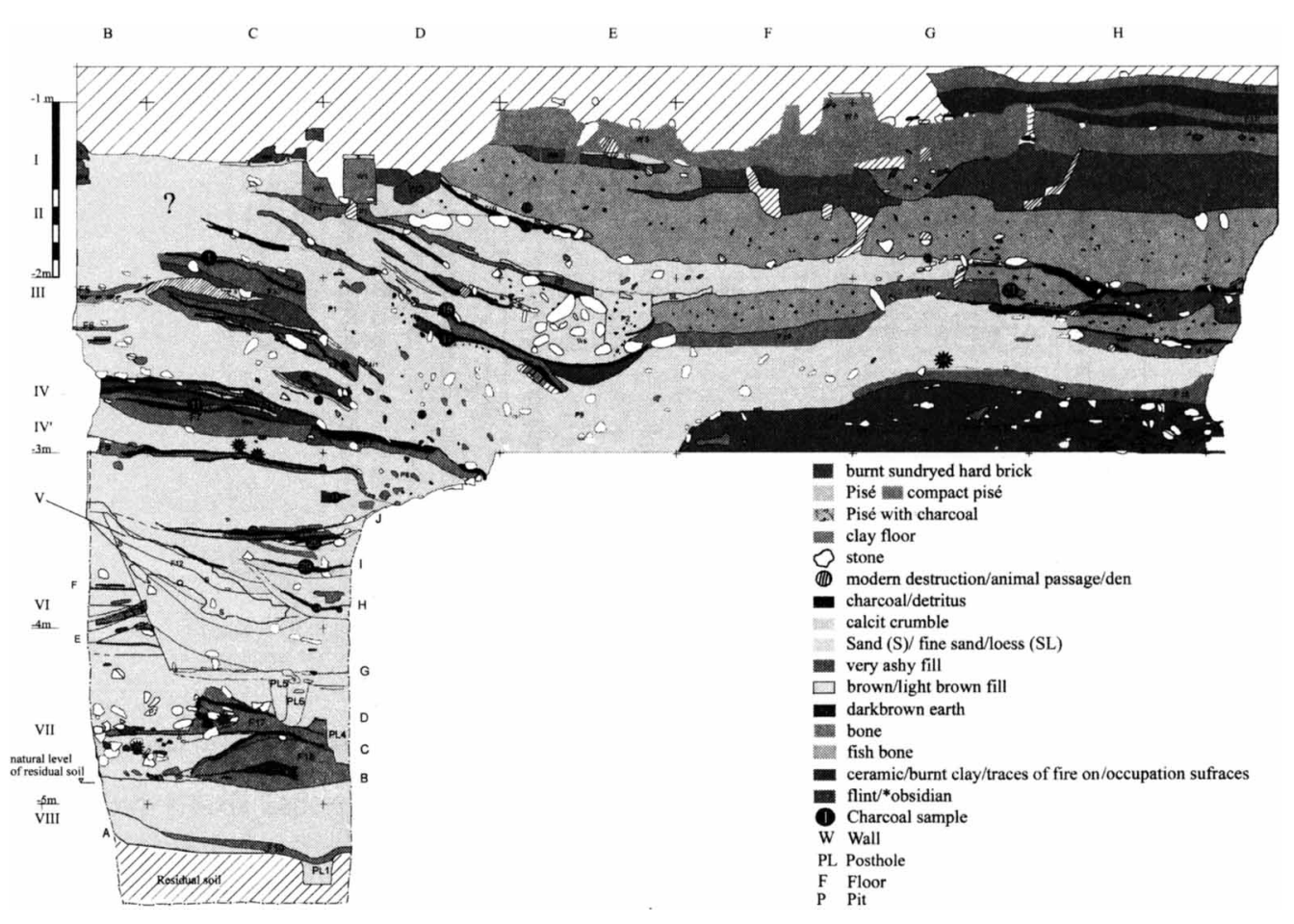

Figure 2 Körtik Tepe, eastern profile of Trench A80 
Eight samples for ${ }^{14} \mathrm{C}$ dating were taken from the different phases by cleaning the trench profile eastward for a distance of $10 \mathrm{~cm}$ to avoid contamination. The precise location of the samples is given in Figure 2. Except for sample $\mathrm{CH} 33$, which comes from a level of $-4.27 \mathrm{~m}$ close to the eastern profile of A80, all samples were taken from the profile itself. Sample $\mathrm{CH} 21$, belonging to the youngest dated phase, is from the filling layer that accumulated after the stone building of $\mathrm{CH}$ 15/ $\mathrm{CH} 17$ had been abandoned. The uppermost layers have not been dated so far. Samples $\mathrm{CH} 15$ and 17 date the foundation pit of the stone wall of Phase II, with $\mathrm{CH} 15$ being only slightly younger than $\mathrm{CH}$ 17. Sample $\mathrm{CH} 1$ was taken from a living floor (or thin destruction layer) between the second and third renewals of the clay construction F5-F4-F3 of Phase III. Sample CH 11 comes from the lowest part of a destruction layer of Phase IV: it might represent either the building itself (burnt construction material), occupational debris of the building (firewood), or material from the building's destruction (burnt wood, matting, or the like) (F 7). Samples CH 26 and CH 29 come from the filling layers of the above-mentioned pit and date thin layers of charcoal (probably firewood) representing ephemeral occupations.

The stratigraphy of A84 (Figure 3) correlates well with A80 due to Trench A85, which was excavated between $A 80$ and $A 84$ in 2010 . At present, the profiles can be correlated down to $-3.24 \mathrm{~m}$. The lowest sample in Trench A84, CH 42, was taken from a filling layer between 2 massive clay floors. $\mathrm{CH} 41$ comes from the occupation phase of the clay floor $\mathrm{F} 4 / \mathrm{F} 4$ '. A more recent sample, $\mathrm{CH} 35$, was taken from a living floor (F3) that had been renovated at least 3 times. The sample $\mathrm{CH} 28$ stems from a destruction layer of F2, one of the most recent early Neolithic floors. The stratigraphic correlation of the samples within Phase IV is partly arbitrary: whereas the relative sequence in Trench A84, $\mathrm{CH} 41$, and $\mathrm{CH} \mathrm{42}$, is clear, $\mathrm{CH} 11$ of Trench A80 could be contemporary with either $\mathrm{CH} 42$ or $\mathrm{CH} 41$, or it could be older, younger, or in between the two. However, its position within Phase IV does not affect the sequencing in any significant way.

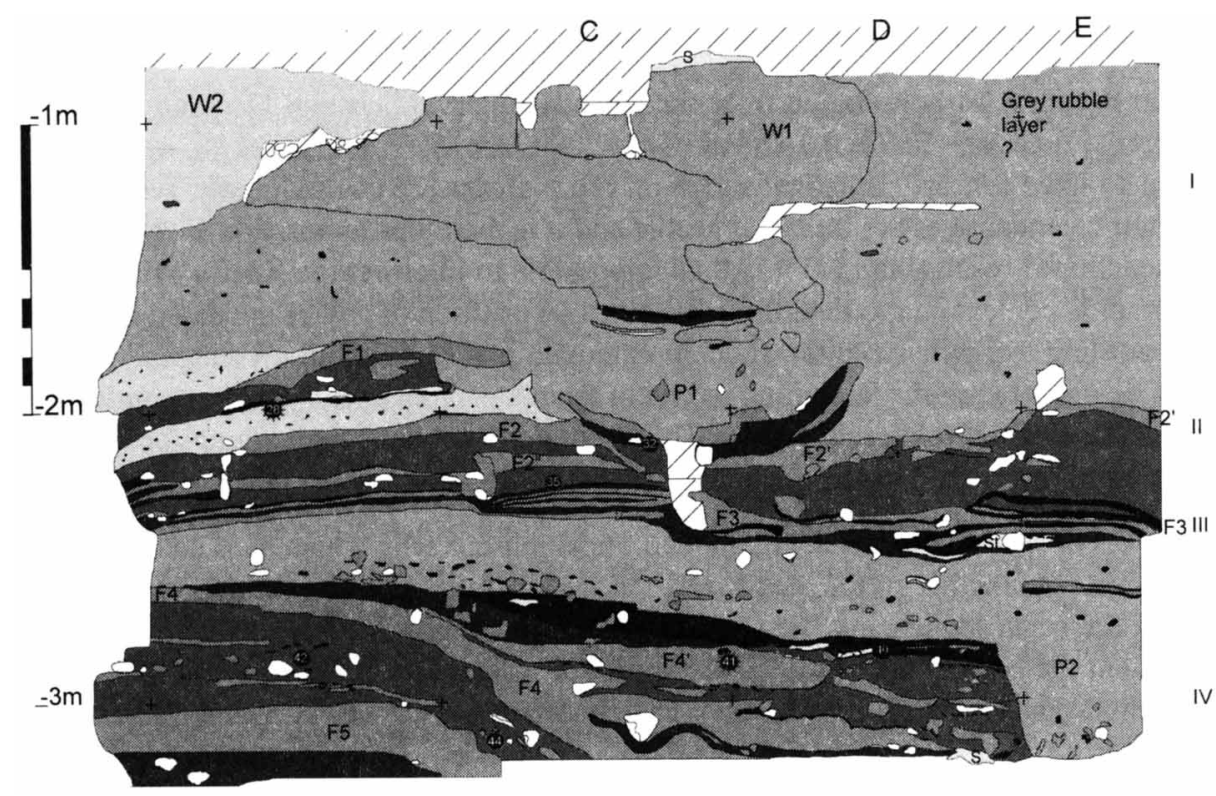

Figure 3 Körtik Tepe, eastern profile of Trench A84 
Most of the samples are from short-lived wood species or small twigs (Table 1). There are 2 samples of oak, 1 of pistachio and 1 undetermined that might show old-wood effects, but compared to the results of the other dates, they seem consistent. At first, we decided not to date seeds because of the high risk that such small items had been dislocated. It should be mentioned that neither phases VII and VIII, the oldest phases of Trench A80, nor the youngest layers have yet been ${ }^{14} \mathrm{C}$ dated: we failed to obtain well-preserved charcoal from the oldest layers; and the risk of contamination in the uppermost layers is very high because the nearby fields are burnt annually.

\section{A Bayesian Approach}

In recent years, Bayesian sequence modeling has gained wide popularity in prehistoric chronological studies, particularly for well-defined stratigraphic data sequences (Bayliss 2009; Bronk Ramsey 2009). The basic idea is to combine ${ }^{14} \mathrm{C}$ ages and archaeological observations to achieve a more precise chronological framework for individual sites and prehistoric processes.

As has been emphasized by all researchers involved in the development of Bayesian approaches to ${ }^{14} \mathrm{C}$ age calibration (e.g. Buck et al. 1996; Bayliss 2009; Bronk Ramsey 2009), Bayesian sequencing (BS) strongly relies on the definition of an adequate archaeological (prior) model. According to Bayes' theorem (Bayes 1763), it is possible to combine measured data (e.g. a series of ${ }^{14} \mathrm{C}$ ages) with additional knowledge. In the present study, we will combine stratigraphic information with the ${ }^{14} \mathrm{C}$ ages in order to refine the probability ranges of the calibrated data. However, under certain conditions, which are not always obvious to the inexperienced user, the method can produce results that have (as requested) higher precision than the individual dates, but which were gained at the cost of a lower overall dating accuracy (Steier and Rom 2000). Taphonomic difficulties in the interpretative "dating" of (often significantly reorganized) organic substances were described recently for the Aegean Late Bronze Age chronology (Weninger and Jung 2009). The specific dating problem on which we will focus here is the existence of a major plateau in the ${ }^{14} \mathrm{C}$ age calibration curve at the transition from the Younger Dryas to the early Holocene.

As shown in Figure 4, samples taken from the calendar interval between 11.6 and $11.3 \mathrm{cal} \mathrm{ka}$ BP, have average ${ }^{14} \mathrm{C}$ ages at $\sim 10.0 \pm 0.1 \mathrm{ka} \mathrm{BP}$ (Benz 2000:40). (1) The $12 \mathrm{ETH}{ }^{14} \mathrm{C}$ ages from Körtik Tepe (Table 1) have a nearly identical range on the plateau. (2) Consequently, without a known sequence their calendar ages are interchangeable and it is therefore impossible to apply a statistical test with meaningful results, and (3) it is thus impossible to interpret the Körtik Tepe data without their stratigraphic context and to determine the accurate position of any of the dated samples on the plateau. According to Bayliss (2009), such an extended plateau without a youngest or oldest date available to delimit at least the beginning or end of the plateau represents the most challenging case for the application of Bayesian sequencing. This scenario is not only challenging for Bayesian calibration, but for all other calibration methodologies.

Therefore, we will first re-address the main theoretical reasons why a plateau is so difficult to manage in Bayesian sequencing. In the analysis of the Körtik Tepe data that follows, we will compare the results of Bayesian sequencing (BS) and Monte Carlo wiggle-matching (MCWM). It should be emphasized that the critical methodological aspects of BS equally apply to the MCWM approach. For both methods, we will study the results of the respective software (OxCal and CalPal) under perhaps the most extreme conditions of data input.

Up to the present, the most detailed study on reactions of BS under plateau conditions is that by Steier and Rom (2000). The conditions they applied can be directly compared to the Körtik Tepe data. Steier and Rom entered a large number of known-age sample sequences into the BS algorithm 


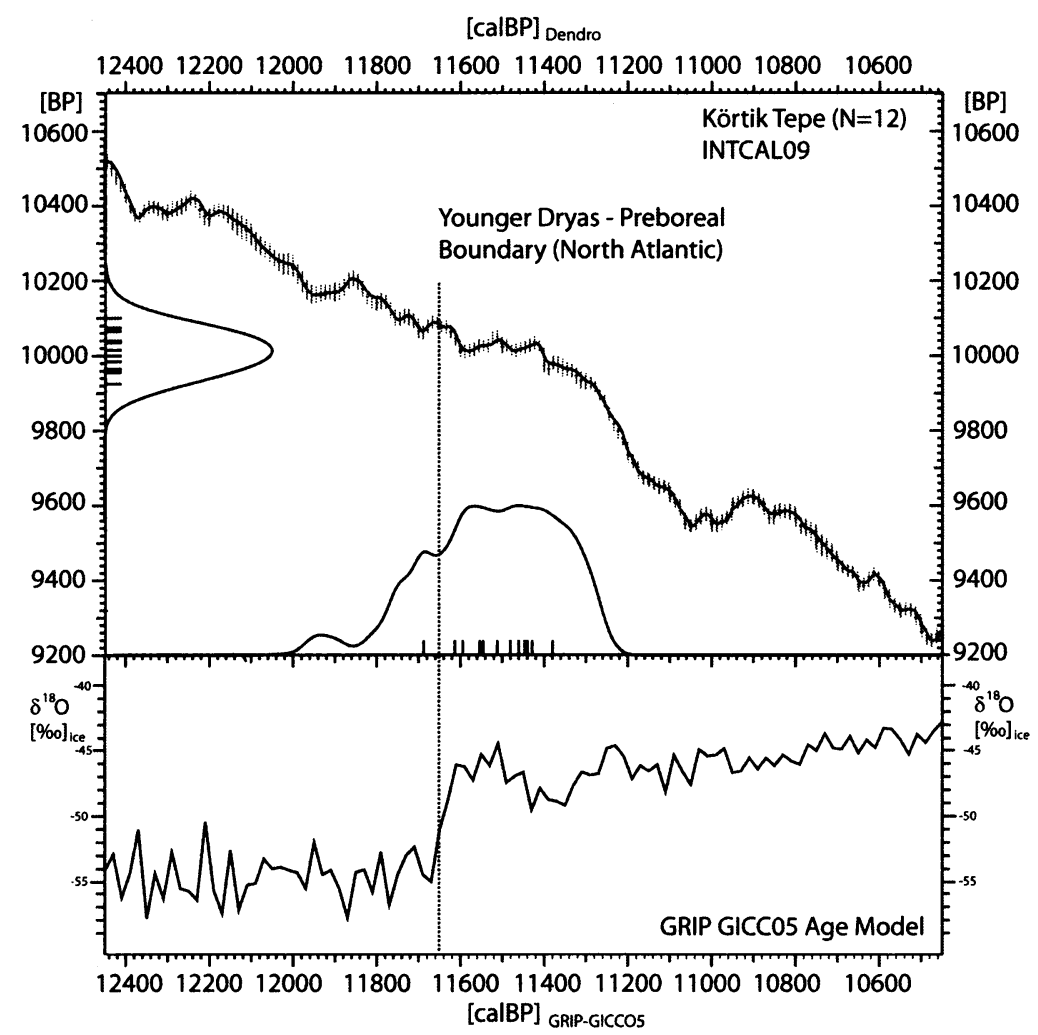

Figure 4 Probabilistic calibration of Körtik Tepe ${ }^{14} \mathrm{C}$ data (Table 1) showing (upper graph) calibration curve IntCal09 (Reimer et al. 2009) with projection of calibration raw data $( \pm 1 \sigma$ error bars) measured by the laboratories of Seattle and Heidelberg, and (lower graph) $20-\mathrm{yr}$ mean Greenland GRIP stable oxygen isotope data (GRIP members 1993) based on GICC05 age model (Andersen et al. 2006; Rasmussen et al. 2006). The position of the Younger Dryas/ Early Preboreal boundary (Vinther et al. 2006) is indicated by a dashed line. Graph produced by CalPal.

of the OxCal program (v 2.18; Bronk Ramsey 1995) and compared the ideal data input with the real program output. Their results can be summarized as follows:

1. The calendar ages are spread across the entire length of the ${ }^{14} \mathrm{C}$ plateau independently of the true sample age.

2. A similar spread is observed under non-plateau ("wiggly") conditions, e.g. when the input data were clustered at the beginning, middle, or end of an extended wiggle sequence.

3. The BS algorithm produces spuriously high dating precision simultaneously with a loss of dating accuracy.

4. All these effects showed up in all regions of the calibration curve, but they are most obvious for the plateaus.

5. The dating artifacts are more obvious for longer (multicentury) sequences, but also exist for short (multidecade) sequences, even for the minimum tested sample of 2 dates.

As was recognized by Steier and Rom (2000) and confirmed by Bronk Ramsey (2000), the main reason for this "failure" of the BS algorithm is the choice of an inadequate archaeological model. When the archaeological prior is (naturally) chosen as a calendar-scale time constant, then the OxCal algo- 
rithm program will spread the archaeological ages as far as possible over the calendar timescale (only limited by the plateau). In the ideal case of a $45^{\circ}$ (linear) calibration curve, this expansion of a sequence would be internally linear in time. For a real (wiggly or flat) calibration curve, the (implicitly) targeted linear expansion is limited by the archaeological ${ }^{14} \mathrm{C}$ ages, their standard deviations, and the shape of the calibration curve. Formulated critically, in order that the BS algorithm can reproduce the true sequence of sample ages accurately and reliably, exactly this sequence must be used as model (cf. Weninger et al. 2011).

There are slight differences in the shape of the plateau Steier and Rom have chosen and the Early Holocene Plateau, which complicate exact comparisons. However, since the standard deviations ( 45 BP) of the Körtik Tepe data and of the model data ( 40 BP) used by Steier and Rom (2000) are nearly identical, we may expect similar reactions of the BS algorithm for the Körtik Tepe data. Using this theoretical background, we will now take a closer look at the results of Bayesian sequencing when applied to the Körtik Tepe data (Figure 5).

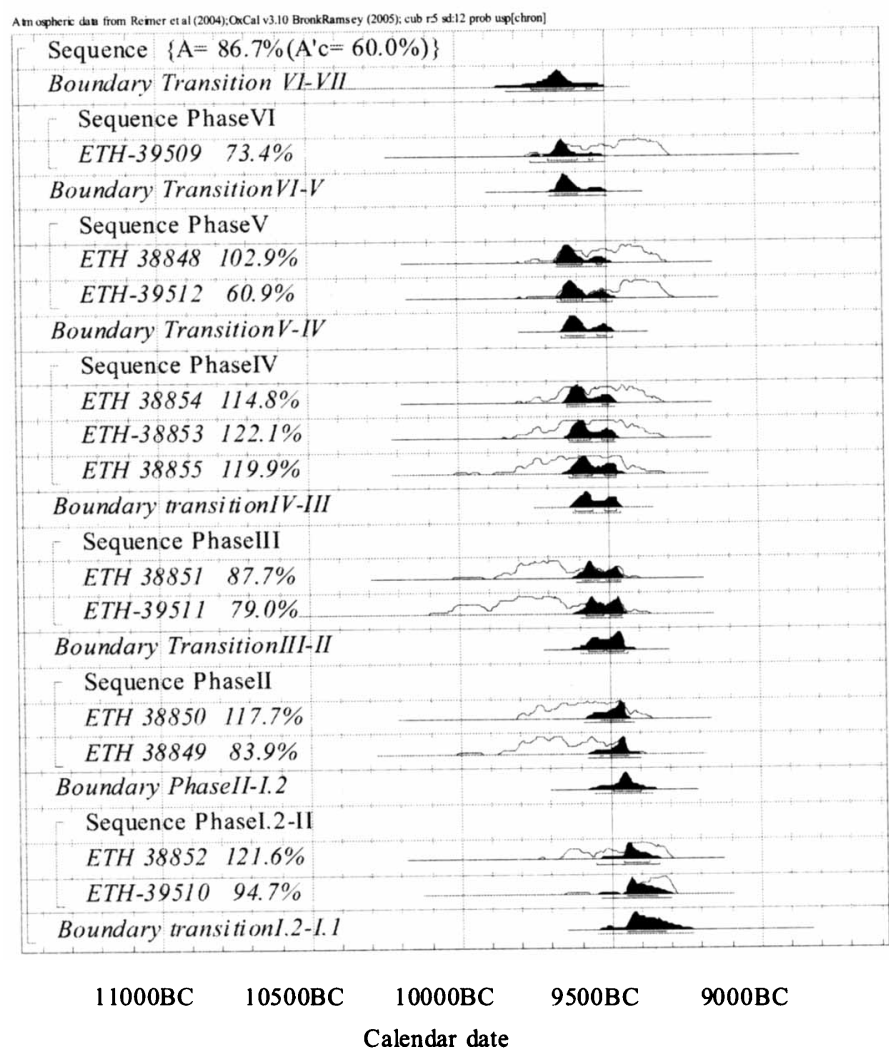

Figure 5 Results of Bayesian sequence (BS) modeling for Körtik Tepe ${ }^{14} \mathrm{C}$ data. The graph shows the single age probability distributions of each input ${ }^{14} \mathrm{C}$ age (light outlined) and the corresponding conditionally refined probability distributions (dark shaded) for the stratigraphically sequenced ${ }^{14} \mathrm{C}$ dates. Graph produced by OxCal. 


\section{Bayesian Sequencing at Körtik Tepe}

The applied Bayesian sequencing (BS) model incorporates the stratigraphic boundary conditions we defined according to the stratigraphic phase model (cf. Figures 2 and 3). The only information entered into the BS model was the stratigraphic order of the dated samples. We used the sequencing algorithm as implemented in $\mathrm{OxCal}(\mathrm{v} 3.10)$ by arranging the ${ }^{14} \mathrm{C}$ data according to the archaeological phases, which were defined by the stratigraphy (Bronk Ramsey 2005).

The main results are (1) the highest probability for the oldest Körtik Tepe phase dates to $\sim 11,640$ $11,480 \mathrm{cal} \mathrm{BP} ;(2)$ the highest probability of the youngest phase dates to $\sim 11,400-11,300 \mathrm{cal} \mathrm{BP}$; (3) the samples from intermediate stratigraphic phases have calendar ages that are positioned in correct (known) order from older to younger ages at approximately linear positions between these 2 age boundaries; and (4) the conditionally refined dating probabilities (cf. Figure 5 dark shaded areas) are positioned symmetrically on the stratigraphically older or younger side of the original uncorrected calibrated age distributions (cf. Figure 5, light outlined) for younger and older samples, respectively.

As expected according to the studies of Steier and Rom (2000), the data of Körtik Tepe are spread over the whole plateau of the Early Holocene. Both the BS age distribution for the stratigraphically oldest phase boundary and for the youngest phase correspond quite well with the respective beginning and end of the Early Holocene plateau (cf. Figure 4). Of course, these boundary values are not sharply defined. Both marginal probability distributions have $95 \%$ ranges of $\sim 200$ calendar yr. The overall agreement of $>86 \%$ demonstrates the high consistency of the measurements and the reliability of the samples.

\section{Monte Carlo Wiggle-Matching}

Because of the remaining problems in the definition of adequate and robust archaeological prior models for Bayesian sequencing (Steier and Rom 2000; Weninger et al. 2010), we compared the OxCal-based BS results with an independent calibration approach. For this purpose, we applied the Körtik Tepe data to Gaussian Monte Carlo wiggle-matching (GMCWM). Bronk Ramsey et al. (2001) provide a critical comparison of the 2 methods. Archaeological applications of GMCWM are described in Weninger and Jung (2009). Here, we only provide a brief outline of the method.

GMCWM is an extension of the wiggle-matching method developed long ago (e.g. Pearson 1986; Weninger 1986). In tree-ring dating, the age difference between the rings is known precisely. The tree-ring ${ }^{14} \mathrm{C}$ data can thus be fitted to the calibration curve based on a $\chi^{2}$ test. At first, the weighted sum of squares for the $2{ }^{14} \mathrm{C}$ data sets (known and unknown age tree-ring data) for a large number of different cal-age settings of the floating tree-ring data is calculated and then the $\chi^{2}$ minimum is selected as the effective best fit. This approach usually gives a definite answer, but in the $\chi^{2}$ test the larger the scatter of the measurements, the narrower the related uncertainty limits that can be looked up in statistical tables. As a solution, in GMCWM the fitting process is repeated a large number of times in order to produce a series of possible solutions. These solutions are then plotted as a histogram that can be analyzed for the best fit. The method thus applies a range of best-fitting results on any requested statistical level (e.g. 68\%, 95\%).

In CalPal software, the GMCWM algorithm fits the calendar seriated ${ }^{14} \mathrm{C}$ age/sample pairs repeatedly to the calibration curve for an optional number of runs between 1 and 10,000. Because the actual cal-age distances of our samples are unknown, we used an extension of the GMCWM procedure whereby the distances are varied uniformly in annual steps between 0 and $50 \mathrm{yr}$ (Horejs and 
Weninger 2012). The aim of the extended GMCWM approach is to identify the overall best-fitting archaeological timespan.

When the Körtik Tepe data (Table 1) is applied to the extended GMCWM generic procedure, with 10,000 iterations per run, we obtain a graph that shows the $\chi^{2}$-based average probability $(p)$ for each assumed sample distance (Figure 6, left). These average probabilities have maximal values ( 98\%) for short sequences, and decrease slowly to $\sim 80 \%$, depending on phase length, for increasingly long sequences. The lower curves of Figure 6 (left) show the corresponding $95 \%$ width of the best-fitting histogram. This $95 \%$ histogram width will be considered as the measure of the achieved dating precision and the corresponding probability as the measure of the unknown dating accuracy. The histogram width is largely independent of the simulated archaeological errors $( \pm 10, \pm 30, \pm 50 \mathrm{yr})$. It has a conspicuous minimum for archaeological sequences that have a 22 -yr sample distance. Among the large set of simulated sample sequences, the algorithm has identified the distance of $22 \mathrm{yr}$ per sample as the overall best-fitting sequence.

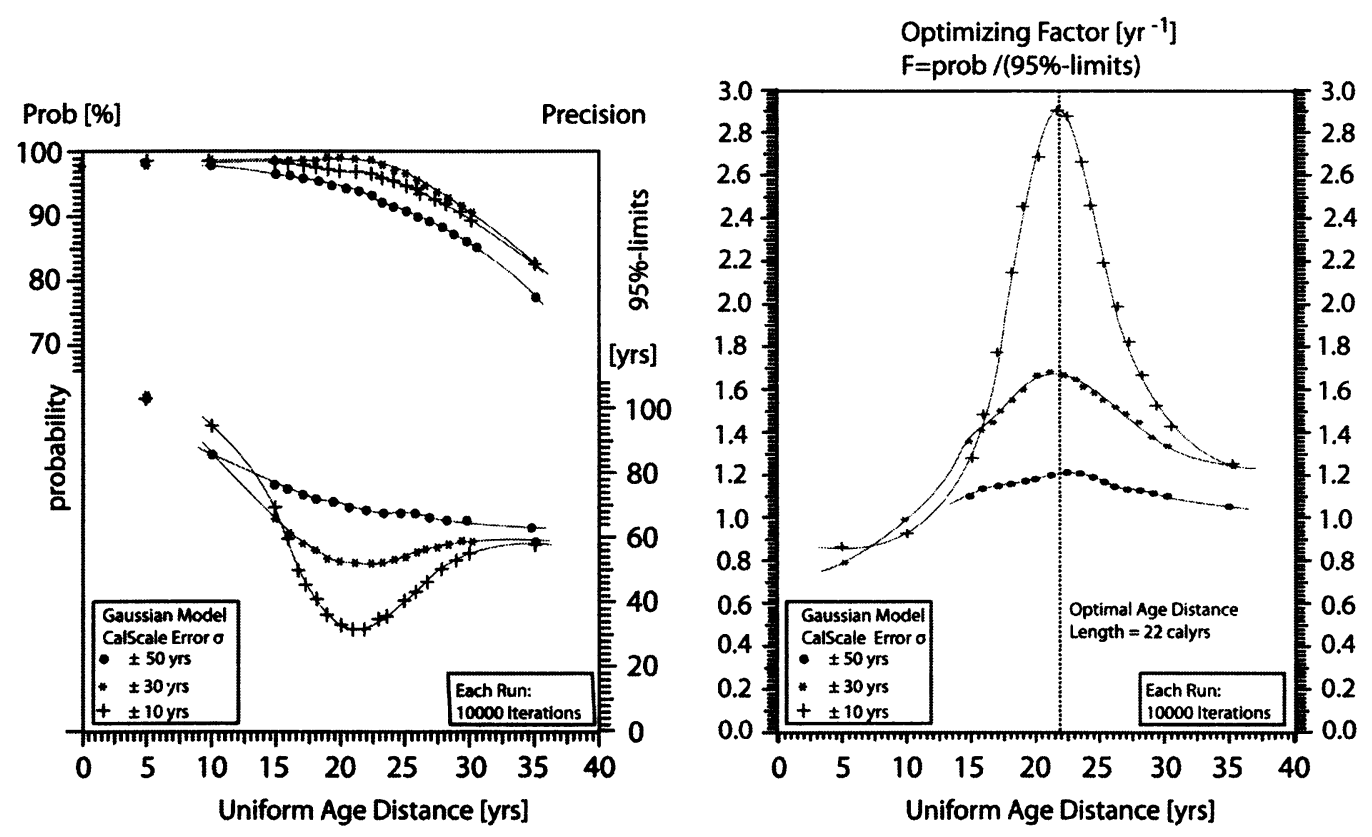

Figure 6 (Left) Results of Gaussian Monte Carlo wiggle-matching (GMCWM) of Körtik Tepe data (Table 1) for simulated uniform sample distances ("phase length") in the range 0-40 cal yr. The graph (left, upper) shows the average $\chi^{2}$-probability for each run (10,000 iterations). The graph (left, lower) shows the $95 \%$ width of each GMCWM histogram (cf. Figure 7, lower). The symbols (dots, stars, crosses) indicate results achieved for different Gaussian modeling errors $( \pm 10, \pm 30, \pm 50 \mathrm{yr}$ ). (Right) Same data as in Figure 6 (left), but shown as optimizing quotient $F$ of the average probability $(p)$ and the $95 \%$ width of the best-fit histogram for each run.

Our second analytical step was to optimize the GMCWM results by defining a factor $F$, the quotient of the average probability $(p)$, and the $95 \%$ width of the best-fit histogram for each run (Figure 6 , right). For all age models, $F$ has a maximum at $\sim 22$ yr. Statistical variations in the position of this maximum appear to be largely independent of the Gaussian errors $( \pm 10, \pm 30, \pm 50$ cal yr). This indicates that the optimizing procedure is quite robust regarding variations in the underlying stratigraphic sample order. 
Our final step was to apply the Körtik Tepe data to GMCWM considering $F$ as an optimal distance of the dates. Figure 7 shows the optimized Körtik Tepe sequence in comparison with the IntCal09 calibration curve and calibration raw data as measured to high precision by the Seattle and Heidelberg laboratories. This graph was produced by the CalPal-Dialog as used in the construction of ${ }^{14} \mathrm{C}$ age calibration curves (Weninger and Jöris 2008). It can be discerned that the ETH measurements clearly mirror the (statistically) quite small step in the calibration curve at calendar ages $\sim 11,400 \mathrm{cal}$ BP. This effective (shorter, but stepped) plateau ( 11,650-11,400+11,400-11,240 cal BP: Figure 7) differs significantly from its initially visualized shape $(\sim 11,650-11,300 \mathrm{cal}$ BP: Figure 4$)$, which is longer. This is not only due to the different graphic resolution (zoom) used in both graphs. By projecting the calibration raw data onto the curve as in Figure 7, the properties of the given data in relation to the raw data of the calibration curve become clear. In fact, the "plateau" is no monolithic entity. All such curve shapes only exist as the result of the combination of the calibration data with the particular archaeological data under study. Similar observations apply to other calibration curve structures (i.e. wiggles).

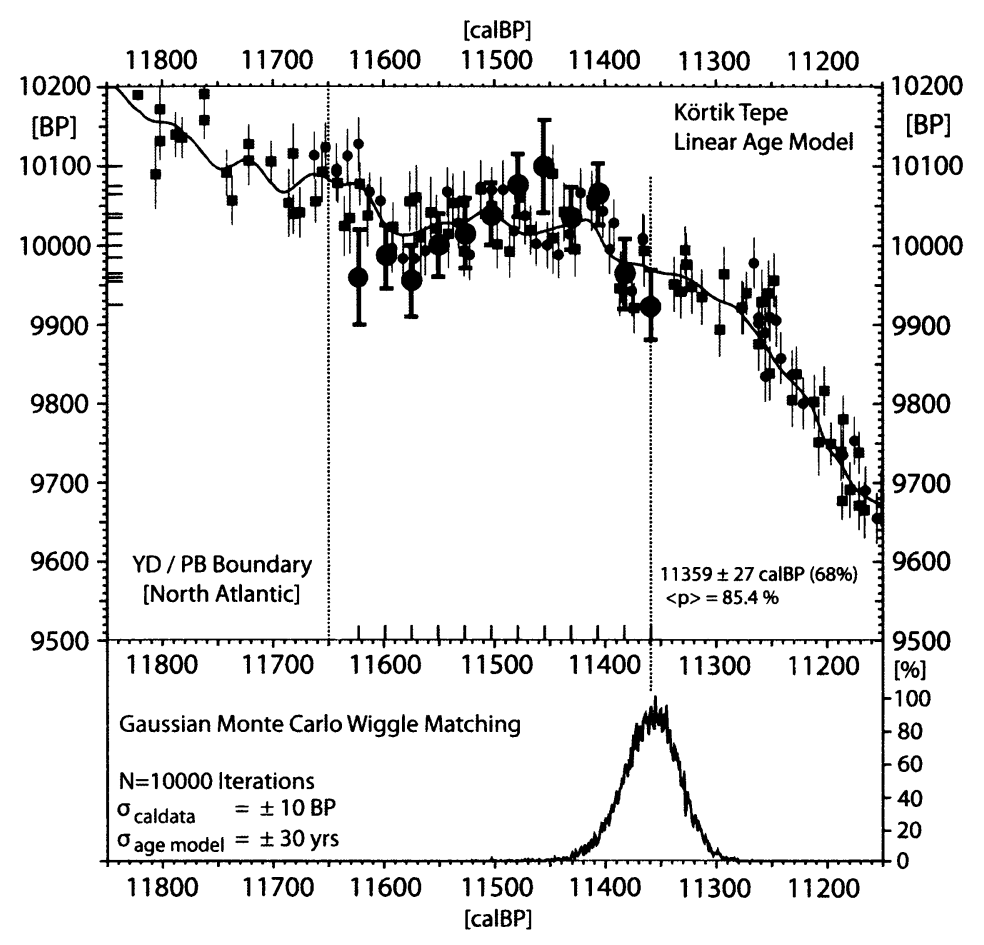

Figure 7 Optimized Körtik Tepe sequence shown in comparison to the IntCal09 curve (Reimer et al. 2009) and underlying high-precision data measured by Seattle and Heidelberg. Graph produced by CalPal.

\section{DISCUSSION}

The results obtained for Körtik Tepe data by Bayesian sequencing (BS) and Gaussian Monte Carlo wiggle-matching (GMWCM) are essentially identical. The main difference between the 2 methods is that in BS the large majority of statistical calculations are performed using the calibrated age distributions, whereas in GMCWM the corresponding calculations are performed using the conventional ${ }^{14} \mathrm{C}$ ages. Despite these different approaches, the comparison of results (cf. Figures 5 and 7) 
demonstrates that both methods recognize that the Körtik data fit well even to minor details of the Early Holocene "plateau."

Both methods calculate the longest and most linear sample sequence that is in statistical agreement with a certain section of the calibration curve. As shown by Steier and Rom (2000), this more-or-less uniform linear arrangement of the data is an inherent result of the BS algorithm. By contrast, in GMCWM a linear and uniform distribution of the dates is an assumption prior to the statistical calculations.

In our view, the main advantage of the BS method is that the underlying algorithm is capable of providing marginal probability distributions for each individual sample. By contrast, the GMWCM application only provides an overall (averaging) probability distribution, which is directly associated only with the youngest sample. But by showing the archaeological data bars in context with the calibration curve raw data, the latter approach allows the researcher to critically evaluate the results: the researcher may shift the archaeological data bars in Figure 7 in both directions (cal-scale and ${ }^{14} \mathrm{C}$-scale) in search of alternative dating for more differentiated distances between phases.

Though both methods apply a roughly linear spread of the data over the whole plateau, the combination of stratigraphic and radiometric information makes a meaningful interpretation of the data possible. More accurate dating could only be obtained by further independent absolute chronological information about the actual intervals between phases.

The above observations have implications for the interpretation of the beginning of Early Neolithic societies. Due to the specific shape of the calibration curve, true readings for samples from the older margin of the plateau will be under-represented in comparison with the spuriously large number of readings that accumulate in the center of the plateau (cf. Figure 4). This effect is enhanced when the probabilities of several hundred dates are summed (e.g. Benz 2000; Aurenche et al. 2001). Dates ranging to the end of the YD have been rare for the central and southern Levant, except for the Harifian in the Negev: only a few sites in the Euphrates/Tigris region (e.g. Tell Qaramel, Qermez Dere, Hallan Çemi, Mureybet: see http://www.exoriente.org/associated_projects/ppnd.php) provide dates in this time range. However, in light of the above results, it might be possible that, although the samples in reality derive from the end of YD, the calibrated readings are artificially shifted to the middle or even to the end of the Early Holocene plateau.

\section{SUMMARY AND CONCLUSION}

Körtik Tepe is the first Epipaleolithic/early Neolithic site on which the transition from the late Younger Dryas (YD) to the earliest Holocene can be clearly dated. By combining radiometric dating with stratigraphic information, it is possible to model the chronological sequence of the Epipaleolithic/early Neolithic occupation more precisely. The results of 2 different calibration programs and sequencing models (Bayesian sequencing with OxCal, and Gaussian Monte Carlo wiggle-matching with CalPal) were compared. Both methods indicate that Phases I.2 to VI date between $\sim 11,600$ and $\sim 11,350$ cal BP. A recently dated rye seed reinforces our earlier suggestion that the lower layers (phases VII and VIII) date to the YD. This is important since it would imply that the occupation of Körtik Tepe started during the YD and then experienced a boom during the earliest Holocene.

Observations from Körtik Tepe of ecological changes and their absolute chronological dating will thus be of great importance for reconstructing the effects of global warming during the Early Holocene on the ecology of that region, and on the social and economic organizations of Early Neolithic societies. 
With regard to the methodological aspects of dating, current studies show that isolated data from the transitional period from the YD to the Early Holocene are always at risk of being interpreted incorrectly when not integrated into a whole sequence of dates. Only a critical and cautious application of calibration programs, accompanied by a fruitful dialogue between archaeologists and ${ }^{14} \mathrm{C}$ laboratories, will help us improve our knowledge of these past societies.

\section{ACKNOWLEDGMENTS}

The German team is grateful to Vecihi Özkaya and his team for their cooperation and support. The description of the stratigraphy and the ${ }^{14} \mathrm{C}$ dates are part of a cooperative project between Kurt W Alt, Institute of Anthropology (AG Alt), Mainz; Simone Riehl and Katleen Deckers, Archaeobotany of the University of Tuebingen; and Marion Benz, Department of Near Eastern Archaeology, Freiburg. We owe our thanks to the German Research Foundation for financial support (AL 287/91, BE 4218/2-1). Elisabetta Boaretto and her team are thanked for the invitation to a most fruitful conference.

\section{REFERENCES}

Arbuckle BS, Özkaya V. 2006. Animal exploitation at Körtik Tepe: an early aceramic site in southeastern Turkey. Paléorient 32(2):113-36.

Andersen KK, Svensson A, Johnsen S, Rasmussen SO, Bigler M, Röthlisberger R, Ruth U, Siggaard-Andersen M-L, Steffensen JP, Dahl-Jensen D, Vinther BM, Clausen HB. 2006. The Greenland Ice Core Chronology 2005, 15-42 ka. Part 1: constructing the time scale. Quaternary Science Reviews 25(23-24):324657.

Aurenche $\mathrm{O}$, Galet P, Régagnon-Caroline E, Évin J. 2001. Proto-Neolithic and Neolithic cultures in the Middle East - the birth of agriculture, livestock raising, and ceramics: a calibrated ${ }^{14} \mathrm{C}$ chronology 12,500-5500 cal BC. Radiocarbon 43(3):1191-202.

Bayes T. 1763. An essay towards solving a problem in the doctrine of chances. Philosophical Transactions of the Royal Society of London 53:370-418.

Bayliss A. 2009. Rolling out revolution: using radiocarbon dating in archaeology. Radiocarbon 51(1):12348.

Benz M. 2000. Die Neolithisierung im Vorderen Orient. Studies in Near Eastern Production, Subsistence, and Environment 7. Berlin: Ex Oriente. 260 p.

Benz M, Coşkun A, Weninger B, Alt KW, Özkaya V. 2011. Stratigraphy and radiocarbon dates of the PPNA site of Körtik Tepe, Diyarbakır. Arkeometri Sonuçları Toplantısı 26:81-100.

Bronk Ramsey C. 1995. Radiocarbon calibration and analysis of stratigraphy: the $\mathrm{OxCal}$ program. Radiocarbon 37(2):425-30.

Bronk Ramsey C. 2000. Comment on 'The Use of Bayesian Statistics for ${ }^{14} \mathrm{C}$ Dates of Chronologically Ordered Samples: A Critical Analysis.' Radiocarbon 42(2): 199-202.

Bronk Ramsey C. 2005. Improving the resolution of radiocarbon dating by statistical analysis. In: Levy TE,

Higham TFG, editors. The Bible and Radiocarbon Dating: Archaeology. Text and Science. London: Equinox. p 57-64.

Bronk Ramsey C. 2009. Bayesian analysis of radiocarbon dates. Radiocarbon 51(1):337-60.

Bronk Ramsey C, van der Plicht J, Weninger B. 2001. 'Wiggle matching' radiocarbon dates. Radiocarbon 43(2A):381-90.

Buck CE, Cavanagh WG, Litton CD. 1996. Bayesian Approach to Interpreting Archaeological Data. Chichester: Wiley. 402 p.

Coşkun A, Benz M, Özkaya V. 2010. Körtik Tepe [WWW document]. URL: http://www.exoriente.org/ associated_projects/ppnd_site.php?s $=81$.

Denaire A. 2009. Radiocarbon dating of the western European Neolithic: comparison of the dates on bones and dates on charcoals. Radiocarbon 51(2):567-74.

Edwards P, Meadows J, Sayej G, Westaway M. 2004. From the PPNA to the PPNB: new views from the Southern Levant after excavations at Zahrat adhDhra' 2 in Jordan. Paléorient 30(2):21-60.

Évin J, Stordeur D. 2008. Chronostratigraphie de Mureybet. Apport des datations radiocarbone. In: Ibáñez JJ, editor. Le site néolithique de Tell Mureybet (Syrie du Nord) 1. British Archaeological Reports. International series 1843 (II) Oxford: Archaeopress. p 24-30.

Finlayson B, Mithen SJ, editors. 2007. The Early Prehistory of Wadi Faynan, Southern Jordan. Wadi Faynan Series 1. Levant Supplementary Series 4. Oxford: Oxbow. $600 \mathrm{p}$.

Greenland Ice-Core Project (GRIP) Members. 1993. Climate instability during the last interglacial period recorded in the GRIP ice core. Nature 364(6434):203-7.

Hajdas I. 2009. Application of radiocarbon dating method. Radiocarbon 51(1):79-90.

Horejs B, Weninger B. 2012. Zur Radiocarbondatierung des frühen und späten Chalkolithikums am Çukurici 
Höyük. In: Horejs B, editor. Çukuriçi Höyük 1. Erste Ergebnisse zum frühen und späten Chalkolithikum. Vienna.

Otte M, Yalçınkaya I, Léotard J-M, López Bayón I, BarYosef O, Kartal M. 1998. Öküzini: un site de chasseurs epipaléolithiques en Anatolie. In: Otte M, editor. Préhistoire d'Anatolie, genèse de deux mondes. Études et Recherches Archéologiques de l'Université de Liège 85(2). Liège: Université de Liège. p 531-49.

Özkaya V, Coşkun A, Benz M, Erdal YS, Atici L, Şahin FS. 2011. Körtik Tepe 2010 Kazısı. Kazı Sonuçları Toplantısı 33(1):315-63.

Pearson GW. 1986. Precise calendrical dating of known growth-period samples using a 'curve fitting' technique. Radiocarbon 28(2A):292-9.

Perrot J. 2000. Réflexions sur l'état des recherches concernant la préhistoire récente du Proche et du MoyenOrient. Paléorient 26(1):5-27.

Rasmussen SO, Andersen KK, Svensson AM, Steffensen JP, Vinther BM, Clausen HB, Siggaard-Andersen ML, Johnsen SJ, Larsen LB, Dahl-Jensen ND, Bigler M, Röthlisberger R, Fischer H, Goto-Azuma K, Hansson ME, Ruth U. 2006. A new Greenland ice core chronology for the last glacial termination. Journal Geophysical Research 111(D6): doi:10.1029/2005JD006079.

Reimer PJ, Baillie MGL, Bard E, Bayliss A, Beck JW, Blackwell PG, Bronk Ramsey C, Buck CE, Burr GS, Edwards RL, Friedrich M, Grootes PM, Guilderson TP, Hajdas I, Heaton TJ, Hogg AG, Hughen KA, Kaiser KF, Kromer B, McCormac FG, Manning SW, Reimer RW, Richards DA, Southon JR, Talamo S, Turney CSM, van der Plicht J, Weyhenmeyer CE. 2009. IntCal09 and Marine09 radiocarbon age calibration curves, 0-50,000 years cal BP. Radiocarbon 51(4): 1111-50.

Riehl S, Benz M, Conard NJ, Darabi H, Deckers K, Fazeli Nashli H, Zeidi-Kulehparcheh M. 2012. Plant use in three Pre-Pottery Neolithic sites of the northern and eastern Fertile Crescent: a preliminary report. Vegeta- tion History and Archaeobotany 21(2):95-106.

Steier P, Rom W. 2000. The use of Bayesian statistics for ${ }^{14} \mathrm{C}$ dates of chronologically ordered samples: a critical analysis. Radiocarbon 42(2): 183-98.

Vinther BM, Clausen HB, Johnsen SJ, Rasmussen SO, Andersen KK, Buchardt SL, Dahl-Jensen D, Seierstad IK, Siggaard-Andersen M-L, Steffensen JP, Svensson AM, Olsen J, Heinemeier J. 2006. A synchronized dating of three Greenland ice cores throughout the Holocene. Journal Geophysical Research 111: D13102, doi:10.1029/2005JD006921.

Weninger B. 1986. High-precision calibration of archaeological radiocarbon dates. Acta Interdisciplinaria Archaeolica 4:11-53.

Weninger B, Jöris O. 2008. A ${ }^{14} \mathrm{C}$ age calibration curve for the last $60 \mathrm{ka}$ : the Greenland-Hulu U/Th timescale and its impact on understanding the Middle to Upper Paleolithic transition in Western Eurasia. Journal of Human Evolution 55(5):772-81.

Weninger B, Jung R. 2009. Absolute chronology of the end of the Aegean Bronze Age. In: Deger-Jalkotzy S, Bächle AE, editors. LH III C Late and the Transition to the Early Iron Age. Vienna: Verlag der Österreichischen Akademie der Wissenschaften. p 373-416.

Weninger B, Clare L, Rohling EJ, Bar-Yosef O, Böhner, U, Budja M, Bundschuh M, Feurdean A, Gebel HG, Jöris O, Linstädter J, Mayewski P, Mühlenbruch T, Reingruber A, Rollefson G, Schyle D, Thissen L, Todorova H, Zielhofer C. 2009. The impact of rapid climate change on prehistoric societies during the Holocene in the Eastern Mediterranean. Documenta Praehistorica 36:7-59.

Weninger F, Steier P, Kutschera W, Wild EM. 2010. Robust Bayesian analysis, an attempt to improve Bayesian sequencing. Radiocarbon 52(3):962-83.

Weninger B, Edinborough K, Clare L, Jöris O. 2011. Concepts of probability in radiocarbon analysis. Documenta Praehistorica 38:1-20. 